Relations industrielles

Industrial Relations

\title{
Worksharing and Layoffs
}

\section{R. W. Crowley}

Volume 34, numéro 2, 1979

URI : https://id.erudit.org/iderudit/028965ar

DOI : https://doi.org/10.7202/028965ar

Aller au sommaire du numéro

\section{Éditeur(s)}

Département des relations industrielles de l'Université Laval

\section{ISSN}

0034-379X (imprimé)

1703-8138 (numérique)

Découvrir la revue

Citer cet article

Crowley, R. W. (1979). Worksharing and Layoffs. Relations industrielles /

Industrial Relations, 34(2), 329-334. https://doi.org/10.7202/028965ar

Tous droits réservés @ Département des relations industrielles de l'Université Laval, 1979
Ce document est protégé par la loi sur le droit d'auteur. L’utilisation des services d'Érudit (y compris la reproduction) est assujettie à sa politique d'utilisation que vous pouvez consulter en ligne.

https://apropos.erudit.org/fr/usagers/politique-dutilisation/ 


\section{Worksharing and Layoffs}

\section{R.W. Crowley}

Worksharing is more common in western Europe than in North America, but it has been receiving increasing attention here. ${ }^{1}$ In Canada, this is partially because of recent changes in federal legislation providing greater incentives for employers and employees to enter worksharing arrangements.

Layoffs rather than worksharing have been the usual response to decreases in levels of economic activity because layoffs compromise neither union emphasis on seniority nor the preoccupation of employers with their right to allocate workers to jobs. As well, labour legislation has been designed generally to accommodate layoffs, and inadvertently may have discouraged alternatives like worksharing. For example, most legislation provides for severance pay and advance notice in case of layoff, but makes no mention of suitable worksharing arrangements.

Worksharing can be simply defined as a reduction in hours worked; in the absence of an equivalent increase in productivity, it has the effect of expanding employment opportunities at a constant level of output. Parenthetically, one might note that some observers have argued that increases in productivity in fact result from such arrangements. ${ }^{2}$

The purpose of this paper is to examine some of the reasons why worksharing has been so slow in coming. The main contention is that the factors noted above have militated against worksharing arrangements even though, in some circumstances, they would have advantages over layoffs. As a policy measure, worksharing makes most sense where decreased production is temporary, for example a cyclical downturn. It is a transitional measure and is not appropriate in situations where an industry is declining and structural labour force adjustment is required. Where permanent reductions are required, other programs, such as adjustment assistance, are more appropriate. ${ }^{3}$

* CROWLEY, R.W., Director General, Central Analytical Services, Canada Department of Labour.

** I am indebted to Tony Wohlfarth for substantial assistance in preparing this paper. An earlier version was presented to the annual meetings of the Canadian Industrial Relations Institute, London, Ontario, May 1978.

1 After preparing this paper, an excellent overview of issues was published: Peter SADLIER-BROWN, Work Sharing in Canada: Problems and Possibilities, Montreal, C.D. Howe Research Institute, June 1978.

2 This opinion is expressed by officials responsible for the Canadian program. As well, c.f., N.J. MCNEFF et. al., "Alternatives to Employee Layoffs: Worksharing and Prelayoff Consultation", Personnel, Vol. 55, No. 1, January-February, 1978, pp. 60-64; and "Measures to Alleviate Unemployment in the Medium Term: Worksharing", Department of Employment (U.K.) Gazette, Vol. 86, No. 4, April 1978, pp. 400-402.

3 Adjustment assistance can be payments either to capital (i.e. industry) or to labour. Most such programs are the former. 
Besides increased productivity, if in fact such an increase occurs, a worksharing program has three benefits. From the employer viewpoint, it facilitates the retention of a skilled labour force, and hence reduces recruitment and training costs when conditions improve. Second, it minimizes the incidence of total layoff and hence the resulting hardship among employees affected. Third, some would see decreased expenditures on unemployment insurance as an advantage.

Recent amendments to the Unemployment Insurance Act remove some of the institutional barriers which previously inhibited the introduction of worksharing arrangements. Under Section 37, introduced in 1977, the Commission is empowered to establish regulations for the operation of a pilot worksharing program. Once a worksharing agreement has been approved, recipients are eligible for unemployment insurance benefits at the regular rate of $662 / 3 \%$ of insurable earnings for those days off the job. Unlike regular benefits, no waiting period is imposed on recipients. Moreover, should total layoff follow a period of a worksharing, regular unemployment insurance entitlement is unaffected. (Benefit levels in such situations, however, may be lowered because the earnings basis for calculating benefits could be lower.)

In effect, Section 37 acts as an exemption from normal unemployment insurance provisions regarding partial employment. Under these regular provisions, an employee working greater than two thirds of normal hours would be disqualified from receiving unemployment insurance benefits.

As of October 1978, twenty-two worksharing agreements had been signed. Only one involved a permanent reduction in work force. The average duration of the agreements is 21 weeks though three have exceeded the 26 week maximum set out in the regulations. 2400 workers have been or are on worksharing and it is estimated about 800 workers otherwise would have been laid off. In many ways this tentative and flexible first step has probably been a very good way to proceed. ${ }^{4}$

\section{EUROPEAN EXPERIENCE}

There is no doubt a lesson to be learned from European experience with worksharing. It is not possible here to provide a detailed examination but a few points of comparison can be drawn. ${ }^{5}$

4 For a description of the experience to date with worksharing, see Department/Commission of Employment and Immigration, unpublished paper, November 1, 1977; "WorkSharing in Canada", unpublished paper, April 1978.

5 For a detailed description of the European work-sharing programs, see Commission of the European Communities, "Work Sharing", unpublished paper, February 20, 1978; Commission of the European Communities, unpublished paper, "Work-sharing - Objectives and Effects", February 24, 1978; Department of Employment and Immigration, "WorkSharing in Europe", unpublished paper, May 20, 1978. SADLIER-BROWN's pamphlet, op. cit., contains a comparison of Canadian and West German programs, pp. 5-8. 
Government sponsored worksharing programs in western Europe all specify a maximum duration. Limits range from a low of 8 weeks in France to just under a year in the worksharing program recently introduced in the United Kingdom. In all these countries worksharing is perceived as a substitute for unemployment insurance. Italy, for example, offers relatively low unemployment benefits, but pays worksharing benefits to provide those on short-time with $80 \%$ of their former gross earnings. Worksharing is most prevalent in West Germany. During their 1975 recession, 775,000 received these benefits, resulting in an estimated reduction of 170,000 persons from the ranks of the unemployed - equivalent to $.8 \%$ decrease in the unemployment rate. ${ }^{6}$

Using such programs inevitably leads to abuses, and this is an area where one can perhaps learn most. One example well documented in Italy is where short-time workers "moonlight" with other part-time jobs. It is obviously difficult to police a system where the incentive may be that earnings with benefits exceed previous earnings. However, this problem may not be extensive if layoffs occur when there is a general recession and employment is difficult to find. Another abuse has been for employers to take advantage of government sponsored worksharing either to permanently reduce their work force or to avoid payroll costs for some workers who would not otherwise be laid off. For example, the services of highly skilled workers may be retained in anticipation of an upturn, even without worksharing incentives. Similarly, it may be easier to "layoff" an employee if an employer knows the government will provide support over an extended period of time. Obviously, these "leakages" are difficult to detect.

\section{WORKSHARING IN COLLECTIVE AGREEMENTS}

Although government-sponsored worksharing programs are novel in Canada, the concept is not entirely alien. In 341 collective agreements involving more than 500 employees in Canadian manufacturing in 1976, 18 per cent made provision for the distribution of work during slack periods. ${ }^{7}$ In general, these clauses require union and management consultation (that is, they are optional) and specify a minimum period prior to an individual being laid-off completely. They are most prevalent in the textile, clothing, and knitting industries - indicating, perhaps, the significant variability of work volume in those industries. There is also tendency for them to be more common in the larger bargaining units - possibly indicating greater awareness of worksharing as an alternative.

The incidence of these clauses tells us nothing about their actual usage, however, and in fact the statistics may be misleading. A U.S. study found

6For a discussion of work-sharing as a policy measure to reduce unemployment, see S.A. LEVITAN and R.S. BELOUS, "Reduced Worktime - Tool to Fight Unemployment", Worklife, Vol. 3, No. 4, April, 1978.

7 Provisions in Major Collective Agreements Covering Employees in Canadian Manufacturing Industries, Ottawa: Labour Canada, 1977. 
that where worksharing and seniority provisions co-exist, the former are rarely used. ${ }^{8} \mathrm{~A}$ further indication of this is the frequency of severance payments and supplementary unemployment benefit clauses in contracts. These payments essentially "sweeten the pot" for those laid-off by supplementing unemployment insurance benefits. Some $58 \%$ of the 341 large collective agreements cited above provided for either severance or supplementary payments.

The incidence of seniority-on-layoff provisions is still another indicator. Fully $95 \%$ of the 341 agreements required that seniority and/or related skill requirements be taken into account in the event of layoff. This is a clear indication of the important role played by the seniority system in protecting job security in the unionized sector. Reflecting management concern with protecting their flexibility, four-fifths of these agreements required consideration of both skill and seniority in considering layoffs.

\section{ARGUMENTS THAT HAVE BEEN USED AGAINST WORKSHARING}

Briefs presented to the Parliamentary Committee examining the Act to amend the Unemployment Insurance Act provide some valuable insight into the principal objections to the worksharing concept. ${ }^{9}$

First, it was argued that worksharing would undermine the collective bargaining process. From the Canadian Labour Congress (CLC) brief:

If collective agreements freely made are in force or under negotiations worksharing as envisaged here could well represent an instrusion into the collective bargaining process. ${ }^{10}$

The Canadian Chamber of Commerce stated in its written brief that:

Collective bargaining agreements are tailored to what the parties believe are matters of substance, and layoff policy is one of these matters. ${ }^{11}$

More forcefully, in its oral brief, the Chamber argued that they prefer to have employer-employees discussing an arrangement without involving the Unemployment Insurance Commission (now CEIC). 12

Union briefs generally reflected concern that worksharing would weaken worker benefits. Again from the CLC submission:

8 HENLE, Peter, Work-Sharing as an Alternative to Layoffs, Washington, Congressional Research Service, Library of Congress, 1976.

9 "Briefs presented to the House of Commons Standing Committee on Labour, Manpower and Immigration”, April - May 1977. For a summary see Lawrence KELL.Y, “WorkSharing: Union and Employer Views", IR Research Reports, Vol. 2, No. 2, November, 1977, pp. 11-14.

10 Brief of the Canadian Labour Congress to the House of Commons Standing Committee on Labour, Manpower, and Immigration, p. 16.

11 Canadian Chamber of Commerce Brief, p. 7.

12 Canadian Chamber of Commerce, oral statement to House of Commons Standing Committee on Labour Manpower and Immigration. 
Not only would all hands have to work for less than their normal earnings but pension plans and other fringe benefits already in place would suffer a depreciation in dollar value. ${ }^{13}$

The United Auto Workers were concerned that worksharing would be beneficial to the employer, and at the same time mask the true dimensions of the unemployment problem:

We are totally opposed to work-sharing programs. Such programs historically tend to subsidize employers. They also give the illusion that the unemployment problem is eased when in fact it is only being shared more evenly by working people. ${ }^{14}$

The argument that worksharing would be a subsidy was also made by management organizations, though in a different form. The Canadian Construction Association posed the question as follows:

What care is to be exercised to ensure that the program does not simply put off the day of wrenching adjustments required for the enterprise to compete sucessfully in the market place? ${ }^{15}$

The Canadian Manufacturers Association concurred, saying that "the scheme could be used to subsidze inefficient businesses."

Management representatives also argued that worksharing would raise labour costs, since fringe benefits would have to be maintained and the sharing of work would imply a loss of specialization and, therefore, a drop in productivity. From the brief by the Employer's Council of British Columbia:

If such a program were instituted, in many cases there would be a lowering of the efficiency level of the operation because jobs cannot easily be broken down into a direct ratio between numbers and skills required... A second major objection to this program is that the employer would incur higher overhead costs. If employees were to be kept on payroll, even though their wages would be supplemented by the government employers would be required to maintain employee benefits. ${ }^{16}$

There is an apparent inconsistency between claims that worksharing both subsidizes and increases labour costs. It is a subsidy only in the sense that it facilitates the retention of a workforce which would otherwise be laid-off. It increases labour costs since most agreements signed to date require the employer to maintain full "fringe" benefits for all employees. The Employment and Immigration Commission views this, probably correctly, as an expenditure in lieu of the higher costs of future recruiting if total layoffs were instituted.

13 Canadian Labour Congress Brief, p. 16.

14 United Auto Workers Brief, p. 7.

15 Canadian Construction Association Brief, p. 15.

16 Employer's Council of British Columbia Brief, p. 8. 
The strongest negative prediction concerning the worksharing proposals was the following statement by the CLC:

We doubt very much that any legitimate union in the Canadian context of that term would be inclined to agree to the projected plan. ${ }^{17}$

Subsequent developments have not borne this out. Of the worksharing agreements signed to date, three-quarters involve accredited bargaining agents. Represented in this group are locals of some of the largest unions in this country. The United Steel Workers of America alone have six such agreements.

There is at least one explanation for this apparent inconsistency. At the level of "high policy", unions are understandably opposed to worksharing. Not only does it threaten the seniority system, but it represents an intrusion into the bilateral bargaining relationship. However, from the perspective of the union local, the venture may be appealing. Seniority issues aside, it is an equitable solution to the layoff dilemma, and it allows the local to retain its full membership.

It is apparent from these briefs that there is a natural conservatism of parties to collective bargaining against worksharing arrangements. But this is not the only obstacle. At least three institutional factors can also be cited.

First, unemployment insurance funds have been unavailable in the past to supplement earnings from partial employment. Of course, recent changes take care of this. Second, the assessment of unemployment insurance premiums does not take account of layoff "risk" evidence in past employment records, and hence provides no incentive to minimize the incidence of layoffs. By contrast the U.S. system of experience rating assesses differential premiums, borne completely by the employer and thereby encourages manpower planning to minimize employment fluctuations. ${ }^{18}$ Third, labourrelated legislation is built around the layoff approach. For example, as mentioned earlier, most legislation contains elaborate layoff procedures but no mention of worksharing and its implications for benefits and the like. Presumably in the near future, various labour jurisdictions will have to examine this closely.

\section{CONCLUSION}

To summarize, the Canadian situation is characterized by a union movement which places emphasis on seniority, private sector employers who guard their right to allocate their workforce to jobs and a government approach which has provided little incentive for partial employment. Under these conditions it is not surprising that worksharing arrangements have not prevailed in this country. If the current pilot program is successful, it might be expected that the attitudes of labour and management will mellow and that government regulations will permanently change to accommodate worksharing arrangements.

17 Canadian Labour Congress, op. cit., p. 16.

18 Cl.ARK, Robert, Adjusting Hours to Increase Jobs - An Analysis of the Options, Special Report No. 15, Washington, National Commission for Manpower Policy, 1977. 